Journal of the Egyptian Society of Parasitology, Vol.43, No.2, August 2013

J. Egypt. Soc. Parasitol., 43(2), 2013: 295 - 302

\title{
SKIN REACTIVITY TO ALLERGENS IN RABIGH AREA, KINGDOM OF SAUDI ARABIA
}

By

\section{MOHAMAD SALAH M. HASSAN ${ }^{1}$, MOUFAG TAYEB ${ }^{2}$, ELAMIR MAHMOUD AMIR ${ }^{3}$, AKRAM MOHAMMAD WALI ${ }^{1}$ AND FAWAZ SIDIG MOHAMED ${ }^{1}$}

Departments of Microbiology ${ }^{1}$, Family Medicines ${ }^{2}$ and Parasitology ${ }^{3}$, Rabigh Medical College, King Abdulaziz University, Jeddah, Saudi Arabia Correspondence: Mohamad Salah Hassan email:msalah777@hotmail.com Tel.: 00966545644723; Fax: 0096624223031

\section{Abstract}

This study determined the pattern of skin prick test reactivity to allergens in patients with airway allergy residing in Rabigh Area, based on data analysis of skin prick test results. Skin prick tests of 160 Saudi attended Al Nakheel Polyclinic between July, 2012 and April, 2013. Allergen extracts set was used to test them.

Out 160 patients, $114(71 \%)$ reacted to one or more allergens, who were 73 $(64 \%)$ adults and $41(36 \%)$ children. The majority of adults $(17.8 \%)$ reacted to six allergens and children (19.5\%) reacted to five ones. The most frequently reacting allergen was house dust mites followed by Candida albicans then Cladosporium spp. The maximum number of positive tests per patients was 13 in adults, compared to 10 in children. A significantly higher proportion of adults were reacting to house dust mites, Aspergillus and Penicillium. Sensitivity to allergens was common in patients with airway allergy residing in Rabigh area

Keywords: Saudi Arabia, House dust mite, Airway allergy, Skin prick test

\section{Introduction}

Exposure to allergens has long been associated with allergic disorders. Many authors worldwide have argued that aeroallergens exposure is the major primary cause of asthma (Sporik et al, 1990; Platts-Mills et al, 1997; ElSherbiny et al, 2010), and the global increases in asthma prevalence resulted of increases in aeroallergens exposure (Maloney and Nowak-Wegrzyn 2007; Almogren, 2009). The allergen exposure produces sensitization and continued exposure leads to the development of bronchial hyperactivity and inflam- mation ending in the clinical asthma (Scheibe et al, 2001). In a sensitized individual, bronchial provocation with a relevant allergen is a way for recruiting eosinophils in lungs and increases bronchial hyperactivity (El-Ghitany and Abd El-Salam, 2012).

Asthma associated allergens are primarily perennial indoor allergens such as house dust mite (HDM), animal dander, and cockroaches (El-Sherbini and Gneidy, 2012). Removing asthmatics from their homes not only decreases the symptoms but a marked reduction in bronchial hyper-reactivity has also 
been observed among these patients (Mazyad et al, 2006). In addition, education of parents and a simple preventive measure to reduce mite allergen exposure has been shown to reduce sensitization to mite allergens in children. Impact of food allergy on the quality of life depends on how easy it is to avoid the related food. Avoidance can prevent the disease but it can be a difficult job.

Skin prick test (SPT) is a major tool in the diagnosis of $\operatorname{IgE}$ mediatedallergy. Skin tests are easily carried out, without absolute contraindications and may also be applied to assess predisposition to asthma. Increased exposure to both indoor and outdoor aeroallergens has been implicated in the sharp rise in the prevalence of allergic diseases such as asthma and rhinitis observed in the Kingdom of Saudi Arabia (KSA) between 1986 and 1995. This is further supported by the fact that a report from Riyadh region has shown that $63.3 \%$ children with asthma react to both indoor and outdoor aeroallergen extracts (Urisu et al, 1999).

This study aimed at evaluation of the status of allergen sensitization in patients with clinical allergy in Rabigh area of KSA.

\section{Subjects, Materials and Methods}

The study group was selected from pediatric and adult patients referred because of allergic disorders with the suspicion of allergy to Al-Nakheel Polyclinic and Laboratory in Rabigh city between July, 2012 and April, 2013. A total of 160 patients from the Rabigh area were assessed in this study. On the basis of history and clinical presentation, 95adults (mean age 27 \pm 15 years) and 55 children (mean $11 \pm 2$ years) were clinically diagnosed as having airway allergy (asthma, rhinitis or both). Fifty (54\%) of adults recruited were females and $45(46 \%)$ were males, whereas 22 children (40\%) were males and $33(60 \%)$ were females. These patients were referred for skin prick test (SPT) to the clinical laboratory of Al-Nakheel polyclinic in Rabigh city. Patients on anti-histamine medication or on long term steroids as well as pregnant women were excluded. The informed consent was obtained from each adult or parents in case of children, after approval of the experimental protocol by the local human ethical committee in Rabigh and Research Ethics Committee at Faculty of Medicine, King Abdul-Aziz University.

A combination of allergen extracts from tree, weed, grass pollens, house dust mites, cockroach, cat and fungal spores was used for SPT. Table 1 shows the details of the set of allergen extracts used in this study. A positive and a negative control were included for each assessment. A drop of each allergen extract was placed on the skin of forearm and the underlying skin was nicked using a fine lancet. The results were recorded after 20 minutes and the test was considered positive if the wheal diameter was equal to or more than 3 millimeters (Almogren, 2009).

Statistical analysis: Chi-square $\left(\chi^{2}\right)$ test was used to analyze correlation between skin test results in adults and children. $\mathrm{P}<0.05$ was considered significant. The analysis was performed for 
paired data using two-tailed Student's $t$ test. $\mathrm{P}<0.05$ was considered significant.

\section{Results}

Out of 160 patients, $114(71 \%)$ reacted to one or more allergens. This group included $73(64 \%)$ adults and 41(36\%) children (Tab. 1). Three (4.1\%) adults and $5(12.2 \%)$ children reacted to single allergen whereas the rest of the patients in both groups reacted to multiple allergens. The majority of adults $(17.8 \%)$ reacted to 6 allergens and children $(19.5 \%)$ reacted to 5 allergens. The maximum number of positive test per patients was 13 in adults, compared to 10 in children.

Table 1: Allergen extracts used for SPT (Nelco-Laboratory, USA)

\begin{tabular}{|l|l|}
\hline \multicolumn{1}{|c|}{ Allergen } & \multicolumn{1}{c|}{ UNIT } \\
\hline Dermato . farinae & $10000 \mathrm{IU} / \mathrm{ML}$ \\
\hline D.pteronyssinus . & $10000 \mathrm{IU} / \mathrm{ML}$ \\
\hline Blomia . & $1000 \mathrm{IU} / \mathrm{ML}$ \\
\hline Blatte germane & $1000 \mathrm{IU} / \mathrm{ML}$ \\
\hline Plumes mélanges & $100 \mathrm{IU} / \mathrm{ML}$ \\
\hline Areplex & $1000 \mathrm{IU} / \mathrm{ML}$ \\
\hline Cat & $100 \mathrm{IU} / \mathrm{ML}$ \\
\hline Date palm & $1000 \mathrm{IU} / \mathrm{ML}$ \\
\hline Alternaria & $100 \mathrm{IU} / \mathrm{ML}$ \\
\hline Candida albicans & $1000 \mathrm{IU} / \mathrm{ML}$ \\
\hline Cladosporium & $1000 \mathrm{IU} / \mathrm{ML}$ \\
\hline Aspergillus mix & $100 \mathrm{IU} / \mathrm{ML}$ \\
\hline Penicillium & $1000 \mathrm{IU} / \mathrm{ML}$ \\
\hline Amarante & $1000 \mathrm{IU} / \mathrm{ML}$ \\
\hline Salsola kali & $1000 \mathrm{IU} / \mathrm{ML}$ \\
\hline Chenopode & $100 \mathrm{IU} / \mathrm{ML}$ \\
\hline Armoise & $100 \mathrm{IU} / \mathrm{ML}$ \\
\hline Mesquite & $100 \mathrm{IU} / \mathrm{ML}$ \\
\hline
\end{tabular}

Table 2: Numbers of SPT reactions in adults and children

\begin{tabular}{|c|c|c|}
\hline Allergen number & Adults positive reactions $(\mathrm{n}=73)$ & Children positive reactions $(\mathrm{n}=41)$ \\
\hline 1 & $3(4.1 \%)$ & $5(12.2 \%)$ \\
\hline 2 & $6(8.2 \%)$ & $4(9.8 \%)$ \\
\hline 3 & $6(8.2 \%)$ & $5(12.2 \%)$ \\
\hline 4 & $10(14 \%)$ & $6(14.6 \%)$ \\
\hline 5 & $7(9.6 \%)$ & $8(19.5 \%)$ \\
\hline 6 & $13(17.8 \%)$ & $5(12.2 \%)$ \\
\hline 7 & $8(11 \%)$ & $3(7.3 \%)$ \\
\hline 8 & $6(8.2 \%)$ & $2(4.9 \%)$ \\
\hline 9 & $6(8.2 \%$ & $2(4.9 \%)$ \\
\hline 10 & $4(5.5 \%)$ & $1(2.4 \%)$ \\
\hline 11 & $2(2.8 \%)$ & - \\
\hline 12 & $1(1.4 \%)$ & - \\
\hline 13 & $1(1.4 \%)$ & - \\
\hline 14 & - & - \\
\hline 15 & - & - \\
\hline 16 & - & - \\
\hline 17 & - & \\
\hline 18 & - & \\
\hline
\end{tabular}


Table 3 No. of positive cases in response to allergens

\begin{tabular}{|l|c|}
\hline Allergen & Positive cases $(\mathrm{n}=114)$ \\
\hline Dermato farinae & 41 \\
\hline D.pteronyssinus & 23 \\
\hline Total Dust mites & 64 \\
\hline Blomia & 19 \\
\hline Blatte germane & 11 \\
\hline Plumes mélanges & 23 \\
\hline Areplex & 24 \\
\hline Cat & 21 \\
\hline Date palm & 27 \\
\hline Alternaria & 7 \\
\hline Candida albicans & 38 \\
\hline Cladosporium & 33 \\
\hline Aspergillus mix & 18 \\
\hline Penicillium & 15 \\
\hline Amarante & 3 \\
\hline Salsola kali & 2 \\
\hline Chenopode & 4 \\
\hline Armoise & 5 \\
\hline Mesquite & 26 \\
\hline
\end{tabular}

Table 4: Comparison of skin test in adults $(\mathrm{n}=73)$ and children $(\mathrm{n}=41)$

\begin{tabular}{|l|l|l|l|}
\hline Allergen & Adults positive reactions & Children positive reactions & P value \\
\hline D. farinae & 32 & 9 & \\
\hline D. pteronyssinus & 19 & 4 & \\
\hline Total Dust mites & $51(69.9 \%)$ & $13(31.7 \%)$ & $\mathrm{p}>0.05$ \\
\hline Blomia. & $11(15.1 \%)$ & $8(19.5 \%)$ & n. s. \\
\hline Blatte germani & $7(9.9 \%)$ & $4(9.8 \%)$ & n. s. \\
\hline Plumes melangees & $14(19.2 \%)$ & $9(22 \%)$ & n. s. \\
\hline Areplex & $13(17.8 \%)$ & $11(15.1 \%)$ & n. s. \\
\hline Cat & $21(28.8 \%)$ & $11(15.1 \%)$ & n. s. \\
\hline Date palm & $19(26 \%)$ & $8(19.5 \%)$ & n. s. \\
\hline Alternaria & $5(6.8 \%)$ & $2(4.9 \%)$ & n. s. \\
\hline Candida albicans & $22(30.1 \%)$ & $16(29 \%)$ & n. s. \\
\hline Cladosporium & $19(26 \%)$ & $14(19.2 \%)$ & p $>0.05$ \\
\hline Aspergillus mix & $16(21.9 \%)$ & $2(4.9 \%)$ & p $>0.05$ \\
\hline Penicillium & $14(19.2 \%)$ & $1(2.4 \%)$ & \\
\hline Amarante & $3(4.1 \%)$ & 0 & n. s. \\
\hline Salsola kali & $2(2.8 \%)$ & 0 & n. s. \\
\hline Chenopode & $3(4.1 \%)$ & $1(2.4 \%)$ & \\
\hline Armoise & $5(6.8 \%)$ & 0 & $14(19.2 \%)$ \\
\hline Mesquite & $22(30.1 \%)$ & & \\
\hline
\end{tabular}

n. s.: non-significant.

The most frequently reacting allergen was HDM followed by Candida albicans and Cladosporium (Tab. 3). Skin pick tests among adults and children (Tab. 4) showed that a significantly higher proportion of adults reacting to HDM, Aspergillus mix and Penicillium.

\section{Discussion}

Allergy is the general non-medical term for a hypersensitivity reaction. It is a reaction of the body's immune system in response to stimuli or a trigger factor (Morsy, 2012). These trigger factors are termed allergens. The aller- 
gen can be anything, as some types of food, pollen, medicines, dust mites, pet dander...etc. (Oh et al, 2004), or even chironomid potent (Morsy et al, 2000). Asthma is one of the common allergic conditions that is a significant public health problem, with alarming trends in prevalence, morbidity, and mortality (Kim et al, 2005). In the present study showed the spectrum of allergen sensitization in patients with airway allergy in Rabigh area. The most common allergen was HDM in children and adults with airway allergy.

A total of $71 \%$ of patients reacted to one or more allergens. Maloney and Nowak-Wegrzyn (2007) found that allergens reactions varied from 24 to $81 \%$. A study examining the allergen spectrum in Chinese population reported HDM allergen to be the most common among patients with airway allergy (Schoenwetter et al, 2004). Yu et al, (2006) showed that the most commonly reacting allergens detected were grass, mountain cedar and dust mites. The varying spectra of allergen sensitization and the diversity of reactions could be due to different populations and regional variations (Wang, 2013).

The skin reactivity to allergen extract is mediated by elevated serum $\operatorname{IgE}$ specific to allergens has been associated with asthma in several studies (Calabria et al, 2007; Dottorini et al, 2007). Both genetic and environmental factors are believed to contribute to this relationship between the presence of specific $\operatorname{IgE}$ to allergens and manifestations of airway allergy.

In genetically predisposed individuals, environmental factors appear to play an important role in sensitization to allergens (Kidon et al, 2004; Bousquet et al, 2005; Rowe et al, 2007).

The amount of allergen exposure necessary for sensitization to occur and the amount necessary to result in symptoms in sensitized individual is however not clearly defined although provisional values have been suggested (Arbes et al, 2005; Bavbek et al, 2006).

Thus, in the present study, the level of sensitization to allergens may therefore reflect the degree of exposure in the environment of these patients. Aerobiological survey is probably the best method of estimating the allergen load affecting the HDM patients (Yassin, 2011).

In Saudi Arabia, allergen sensitization in different regions on focused on asthmatic children with asthma, using different sets of allergens than that used in the present study (Al-Nahdi and Al-Quorain 1987; Al-Frayh et al, 1992). It is difficult to draw conclusions on the basis of comparison of these studies since they were carried out in different regions and environmental conditions, but it may reflect difference in environmental allergens.

While residing in an area where both the adults and children were exposed to similar allergen load some interesting observations were made when allergen reactivity was compared. Cross reactivity between $D$. pterronyssinus and $D$. farina was common in adults compared to children. Pollen reactivity was high for both the groups; however children appear to be more sensitive ( $\mathrm{Yu}$ et al, 2012). 
A higher number of children reacted to Blomia allergen compared to adults.

On the contrary, the adults were reacting to moulds more often than the children (Ronmark et al, 2003). It was difficult to explain this discrepancy on the basis of existing data but these findings suggested that the maturation of airways with the advancing age may influence the allergen sensitization status of the atopic individuals and may have a bearing on the manifestations of the allergic diseases in children and adults (Cohn et al, 2006).

\section{Conclusion}

House dust mites (HDM) contain a large number of components that react with IgE in individuals with allergies and induced sensitization and allergic diseases. The outcome results showed that the sensitivity to allergens was common in patients with airway allergy residing in Rabigh area.

No doubt, the extensive aerobiological survey of Saudi Arabia and simultaneous assessment of aeroallergen sensitization by SPT and detection of specific IgE in the respective allergic population would help to access the impact of environmental aeroallergen load on airway allergy.

\section{Acknowledgements}

This Study was kindly funded by The Deanship of Scientific Research, (DSR), King Abdulaziz University, the Kingdom of Saudi Arabia

The authors would like to acknowledge with sincere thanks DSR for the technical advice and the financial support.

\section{References}

Al-Frayh, A, Gad-El-Rab, M, Al-Najjar, A, Hasnain, S, 1992: A comparative study of immediate skin test reactivity to inhalant allergens in asthmatic children of two different regions in Saudi Arabia. Ann. Saudi Med. 12, 5:468 -71 .

Al-Nahdi, M, Al-Quorain, AA, 1987: Sex distribution and common allergens of bronchial asthma in a Saudi Arabian (eastern province) population. Allergol. Immunopathol. (Madr), 15, 6:389-91.

Almogren, A. 2009. Airway allergy and skin reactivity to aeroallergens in Riyadh. Saudi Med. J. 30, 3:392-6.

Arbes, SJ, Gergen, JrPJ, Elliott, L, Zeldin, DC, 2005: Prevalences of positive skin test responses to $10 \mathrm{com}$ mon allergens in the US population: results from the third National Health and Nutrition Examination Survey. J. Allergy Clin. Immunol. 116, 2:377-83.

Bavbek, S, Erkekol, FO, Ceter, T, Mungan, D, Ozer, F, et al, 2006: Sensitization to Alternaria and Cladosporium in patients with respiratory allergy and outdoor counts of mold spores in Ankara atmosphere, Turkey. J. Asthma 43, 6:421-6.

Bousquet, J, Annesi-Maesano, I, Carat, F, Leger, D, Rugina, M. et al, 2005: Characteristics of intermittent and persistent allergic rhinitis: Dreams study group. Clin. Exp. Allergy 35, 6: 728-32.

Calabria, CW, Dice, JP, Hagan, LL, 2007: Prevalence of positive skin test responses to 53 allergens in patients with rhinitis symptoms. Allergy Asthma Proc. 28, 4:442-8. 
Cohn, RD, Arbes, SJ, Jaramillo, Jr R, Reid, LH, Zeldin, D, 2006: National prevalence and exposure risk for cockroach allergen in U.S. households. Environ. Hlth. Perspect. 114, 4:522-6.

Dottorini, ML, Bruni, B, Peccini, F, Bottini, P, Pini, L, et al, 2007: Skin prick-test reactivity to aeroallergens and allergic symptoms in an urban population of central Italy: a longitudinal study. Clin. Exp. Allergy 37, 2:188-96

El-Ghitany, EM, Abd El-Salam, M M, 2012: Environmental intervention for house dust mite control in childhood bronchial asthma. Environ. Hlth. Prev. Med. 17, 5:377-84.

El-Sherbini, GT, Gneidy, MR, 2012: Cockroaches and flies in mechanical transmission of medical important parasites in Khaldyia Village, El-Fayoum, Governorate, Egypt. J. Egypt. Soc. Parasitol. 42, 1:165-74.

El-Sherbiny, GT, El-Sherbini, ET, Saleh, NM, Haridy, FM, Morsy, AT, 2010: A study on the prevalence of house dust mites in Al-Arish City, North Sinai Governorate, Egypt. J. Egypt. Soc. Parasitol. 40, 1:57-70.

Kidon, MI, See, Y, Goh, A, Chay, $O$ M, Balakrishnan, A, 2004: Aeroallergen sensitization in pediatric allergic rhinitis in Singapore: is air-conditioning a factor in the tropics? Pediatr. Allergy Immunol. 15, 4:340-3.

Kim, KH, Kim, KT, Lee, SK, Park, HS, Lee, YM, et al, 2005: Sensitization rates for inhalant allergens in patients with respiratory allergy in Busan. Korean J. Asthma Allergy Clin. Immunol. 25:59-63.
Maloney, J, Nowak-Wegrzyn, A, 2007: Educational clinical case series for pediatric allergy and immunology: allergic proctocolitis, food protein-induced enterocolitis syndrome \& allergic eosinophilic gastroenteritis with protein-losing gastroenteropathy as the manifestations of non-IgE-mediated cow's milk allergy. Pediatr. Allergy Immunol. 18, 4:360-7.

Mazyad, SA, Mohammad, KA, Khalil, HH, 2006: Allergic reactions in patients suffering from asthma induced by house dust mites which treatment by juvenile hormone. J. Egypt. Soc. Parasitol. 36, 2:S31-48.

Morsy, TA, 2012: Insect bites and what is eating you? J. Egypt. Soc. Parasitol. 42, 2:291-308.

Morsy, TA, Saleh, WA, Farrag, AM K, Rifaat, MMA, 2000: Chironomid potent allergens causing respiratory allergy in children. J. Egypt. Soc. Parasitol. 30, 1:83-92.

Oh, JW, Pyun, BY, Choung, JT, Ahn, KM, Kim, CH, et al, 2004: Epidemiological change of atopic dermatitis and food allergy in school-aged children in Korea between 1995 and 2000. J. Korean Med. Sci. 19:716-23.

Platts-Mills, TA, Sporik, RB, Chapman, MD, Heymann, PW, 1997: The role of domestic allergens. Ciba Found Symp, 206:173-85.

Ronmark, E, Perzanowski, M, Mills, T, Lundback, B, 2003: Different sensitization profile for asthma, rhinitis, and eczema among 7-8-year-old children: report from the obstructive lung disease in northern Sweden studies. Pediatr. Allergy Immunol. 14, 2:91-99. 
Rowe, J, Kusel, M, Holt, BJ, Suriyaarachchi, D, Serralha, M, et al, 2007: Prenatal versus postnatal sensitization to environmental allergens in a highrisk birth cohort. J. Allergy Clin. Immunol. 119, 5:1164-73.

Schoenwetter, WF, Dupclay, L, Appajosyula, Jr,S, Botteman, MF, Pashos, C L, 2004. Economic impact and quality-of-life burden of allergic rhinitis. Cur. Med. Res. Opin. 20, 3:305-17.

Sporik, R, Holgate, ST, Platts-Mills, TA, Cogswell, JJ, 1990: Exposure to house-dust mite allergen (Der p I) and the development of asthma in childhood. A prospective study. N. Engl. J. Med. 323, 8:502-7.

Urisu, A, Yamada, K, Tokuda, R, Ando, H, Wada, E, et al, 1999: Clinical significance of IgE-binding activity to enzymatic digests of ovomucoid in the diagnosis and the prediction of the outgrowing of egg white hypersensi- tivity. Int. Arch. Allergy Immunol. 120, 3:192-8.

Wang, JY, 2013: The innate immune response in house dust mite-induced allergic inflammation. Allergy Asthma Immunol. Res. 5, 2:68-74.

Yassin, MK, 2011: Allergenic Dermatophagoides mites causing asthma among schoolchildren at Ain-Shams District, Cairo, Egypt. J. Egypt. Soc. Parasitol. 41, 1:47-54.

Yu, JS, Lee, CJ, Lee, HS, Kim, J, Han, Y, et al, 2012: Prevalence of atopic dermatitis in Korea: analysis by using national statistics. J. Korean Med. Sci. 27:681-5

Yu, JW, Pekeles, G, Legault, L, McCusker, CT, 2006: Milk allergy and vitamin D deficiency rickets: a common disorder associated with an uncommon disease. Ann. Allergy Asthma Immunol. 96, 4:615-9. 